\title{
Іван Романюк
}

Вінницький державний педагогічний університет імені Михайла Коцюбинського доктор історичний наук, професор (Україна) E-mail: ivanvin811@ gmail.com

ORCID: https://orcid.ord/0000-0002-6427-9227

ResearcherID: AAB-4381-2020

\section{Падалка С. С., Кириленко І. Г., Вергунов В. А. Аграрна історія України: у трьох частинах Частина 1. Від найдавніших часів до початку XX століття. Київ: Аграрна наука, 2019. 332с. Частина II: Радянська доба 1917-1990рр. Київ: Аграрна наука, 2019. 458 с. Частина III: Період незалежності 1991-2018 рр. Київ: Аграрна наука, 2019. 372 c.}

\begin{abstract}
Анотація. У статті прорецензовано навчальний підручник у трьох частинах, у якій відомі автори, використовуючи насамперед документальні джерела, напрацювання вітчизняних і зарубіжних дослідників, розкрили аграрні відносини в Україні від найдавніших часів до сьогодення. Особливу увагу приділено питанням щодо змін у сільському господарстві, у соціально-економічному житті села, середовищі селянства, повсякденності українського села. Знання досвіду минулого аграрного ладу може стати надійною основою свідомого вибору оптимальних шляхів подальшого поступу України як демократичної і заможної держави.
\end{abstract}

Ключові слова: Україна, село, аграрні відносини, культура, політика, сільське господарство.

Пропонований авторами навчальний посібник містить досить ґрунтовний виклад матеріалу, який розкриває основні процеси, що відбувалися в аграрній сфері України 3 найдивніших часів і до сьогодення. Він розрахований передусім на студенів та аспірантів вишів України, які навчаються за спеціальностями історія та археологія. Незважаючи на те, що з курсу історії України для закладів вищої освіти існує велика кількість навчально-методичної літератури, на жаль, поки що немає ґрунтовного спеціального посібника, який би забезпечував засвоєння в галузі аграрної історії, досягнень світової та вітчизняної наукової думки. Зазначений посібник певною мірою може заповнити цю прогалину.

Автори посібника намагалися врахувати ту обставину, що у вітчизняній історичній науці впродовж тривалого часу зберігалося співіснування двох концептуальних підходів при висвітленні предмета і завдання курсу агарної історії України. Перший з них твердив, що на кожному етапі характер життя людей, їх політичні, соціальні й економічні відносини, моральні та правові норми завжди визначалися способом добування матеріальних благ, тобто способом виробництва, який включав у себе продуктивні сили і виробничі відносини людей. Другою парадигмою й основою при викладанні курсу Аграрна історія України, її центральною віссю було право українського народу на самовизначення й пошук його оптимальних форм і варіантів. Автори переконані, що засвоєння досягнень вітчизняної та світової наукової думки передбачає відмову від необхідності створення єдиних універсальних засад, на основі яких могли б писати свої праці історики.

Автори намагалися врахувати, що глибоке осмислення аграрної еволюції сприятиме подальшій консолідації українського суспільства.

Так, у першій частині посібника, по-новому з'ясовано типові явища у системах землеробства та агрокультурі, показані різні аспекти розвитку аграрної сфери України. Обрані хронологічні межі охоплюють утворення на території держави первісного суспільства, зародження феодальної державності, започаткування нового періоду історичного розвитку товарно-грошових відносин.

Другу частину посібника присвячено одному з найскладніших і найдраматичніших періодів української історії 1917-1991рр. Посібник розкриває основні процеси, що відбувалися в агарній сфері України від національної революції 1917-1921рр. до проголошення незалежності України. Радянська доба вирізнялася протиборством між владою і селянством. Українському селу довелося переживати запеклу збройну агресію більшовиків проти УНР, три голодомори, анексії, масові депортації, каральні акції, економічні кризи тощо. Змістовна частина посібника врахувала напрацювання вітчизняної і зарубіжної історіографії проблем радянської доби. Окрему увагу автори звертали на питання здобутків і вад радянської системи управління сільським господарством. 
Третю частину пропонованого авторами навчального посібника присвячено важливому періоду історії України, який почався 1991 р. після проголошення державної незалежності. Кінець XX - поч. XXI ст. став історичним періодом, коли відбувалося чергова соціальноекономічна переорієнтація аграрного розвитку України, а також тенденціями еволюції світового аграрного господарства. Ставши одним зі світових лідерів з торгівлі зерновими, водночас виробничо-експортні успіхи залишалися не співвідносними з соціально-економічним занепадом села та істотним зниженням рівня продовольчої безпеки України. Характерними ознаками українського села стали бідність, безробіття, низький рівень зарплати. У цій частині посібника зроблено спробу підсумкової характеристики й оцінки змін у сільськогосподарському розвитку України до 2018 року. До того ж ставилося завдання розглянути визначальні чинники аграрних перетворень, з'ясувати причини кризового стану на селі та перепитії аграрної політики.

Отже, у рецензованому посібнику зважено репрезентовано усю складність і суперечливість процесів, що протікали на селі від найдавніших часів до сьогодення. Його призначення полягає у тому, щоб надати студентам, здобувачам методичну й інформаційну допомогу при вивченні аграрної історії України.

Видання, поза сумнівом, зацікавить істориків, студентів, викладачів, широкий загал читачів, котрих цікавить історія України.

\section{Иван Романюк \\ Винницкий государственный педагогический университет имени Михаила Коцюбинского доктор исторический наук, профрессор (Украина)}

\section{Падалка С. С., Кириленко И. Г., Вергунов В. А. Аграрная история Украины: в трех частях \\ Часть І. От древнейших времен до начала XX века. Киев: Аграрная наука, 2019. 332с. Часть II: Советское время 1917-1990 гг. Киев: Аграрная наука, 2019. 458 с. \\ Часть III: Период независимости 1991-2018 гг. Киев: Аграрная наука, 2019. 372 с.}

Аннотация. В статье прорецензировано учебное пособие в трех частях, в котором известные авторы, используя прежде всего документы источники, наработки отечественных и зарубежных исследователей, раскрыли аграрные отношения в Украине от древнейших времен до современности. Особое внимание уделено вопросам изменений в сельском хозяйстве, в социально-экономической жизни села, среди крестьянства, повседневности украинского села. Знание опыта прошлого аграрного строя может стать надежной основой сознательного выбора оптимальных путей дальнейшего развития Украины как демократического и богатого государства.

Ключевые слова: Украина, село, аграрные отношения, культура, политика, сельское хозяйство.

\section{Ivan M. Romaniuk \\ Vinnytsia Mykhailo Kotsiubynskyi State Pedagogical University Dr (History), Professor (Ukraine)}

Padalka S.S., Kirilenko I.G., Vergunov V.A. Agrarian History of Ukraine: in Three Parts Part 1. From Ancient Times to the Beginning of the XXth century. Kyiv: Agrarian Science, 2019. 332p.

Part II: Soviet Period 1917-1990 Kyiv: Agrarian Science, 2019. 458 p. Part III: The Period of Independence 1991-2018. Kyiv: Agrarian Science, 2019. 372p.

Abstract. The article reviews the textbook in three parts, in which well-known authors using primarily source documents, the work of domestic and foreign researchers have revealed agrarian relations in Ukraine from ancient times to the present. Particular attention is paid to issues of change in agriculture, socio-economic life of the village, the environment of the peasantry, the daily life of the Ukrainian countryside. Knowledge of the experience of the past agrarian system can become a reliable basis for a conscious choice of optimal ways of further progress of Ukraine as a democratic and prosperous state.

Key words: Ukraine, village, agrarian relations, cultures, politics, agriculture.

Статтю надіслано до редколегії 07.02.2021 p. Статтю рекомендовано до друку 12.03.2021 р. 